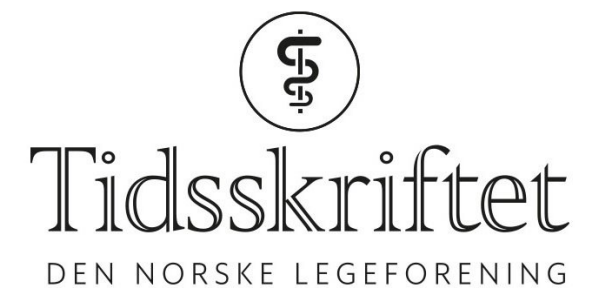

DEN NORSKE LEGEFORENING

\title{
Kjønnspluralisme og NIPT-testen
}

KOMMENTAR

\section{FRED ANDERSEN}

E-post: frea@online.no

Fred Andersen er pensjonert allmennlege og samfunnsmedisiner (MD, ph.d.).

Ingen oppgitte interessekonflikter.

I en lederartikkel av medisinsk redaktør Ketil Slagstad anvendes uttrykk som religiøs fundamentalisme, nasjonalkonservatisme samt «autoritære heteroseksuelle, aldrende menn» som karakteristikk av personer eller miljøer som er kritiske til det ideologiske bidraget enkelte forskningsmiljøer gir til populistisk kjønnspluralisme (1). Artikkelen redegjør for nylig identifiserte genetiske markerer på Y-kromosomet (SRY-genet) og deres bidrag til utviklingen av gonader og til samspillet mellom genetiske mekanismer ved kjønnsutviklingen. Kunnskapsutviklingen på dette feltet er viktig, men når det sammenblandes med ideologiske føringer, er det problemet oppstår.

Misdannelser av indre og ytre kjønnsorganer har vært kjent gjennom hele menneskets historie. I Norge fødes det 10-12 barn per år med uklare kjønnskarakteristika (2). Det er først de siste årene den bakenforliggende årsak gradvis avdekkes idet det er identifisert epigenetiske avvik i markører for dannelsen av anatomiske kjennetegn for kjønn (3).

Artikkelen berører ikke hvor problemet med kjønnspluralisme egentlig ligger. Den sier ingen ting om det er noen sammenhengen mellom de nylig identifiserte epigenetiske mekanismene for kjønn og seksuell legning. Kan det tenkes at seksuell legning er betinget av genetiske markører som overstyrer kjønnskromosomene? Er det i så fall en ønsket kunnskap? Dersom ulike typer seksuell legning er genetisk betinget, da vil det være mulig å sjekke seksuell legning via fosterets DNA i mors blod tidlig i svangerskapet (NIPT - noninvasive prenatal testing) (4). Vi er ikke der ennå. Det vil eventuelt ta tid å utvikle slike tester, men hvis det skjer, står vi overfor et nytt genetisk syndrom som kan «sorteres bort» før uke 13. For det kan kanskje være foreldrepar som kun ønsker barn der det er sammenheng mellom seksuell legning og fysiognomi, foreldre som er religiøse fundamentalister, nasjonalkonservative eller autoritære heteroseksuelle. Vil man i så fall, som liberal populist - eller som transhumanist (5) - kunne legge til rette for en slik anvendelse av NIPT-testen? Bare tanken er hårreisende, men den illustrer en annen side ved den dagsaktuelle populistiske trenden, nemlig hvilke uhyrlige konsekvenser tidlig NIPTtest kan få.

Det artikkelen i virkeligheten handler om er epigenetiske mekanismer som kan medføre misdannelser av genitalia, ikke en genetisk dokumentasjon på forekomsten av flere enn to kjønn. Det er ikke fra den lille gruppen med fysiske misdannelser i kjønnsorganene det massive kravet om kjønnspluralisme kommer. Derfor er det faktisk irrelevant av medisinsk redaktør i Tidsskriftet å sette ideologisk kjønnspluralisme inn i en biologisk sammenheng. 
LITTERATUR:

1. Slagstad K. Ikke begge. Alle kjønn. Tidsskr Nor Legeforen 2018;138. doi:10.4045/tidsskr.18.o888. [PubMed][CrossRef]

2. Diseth TH. Barn født med uklare kjønnskarakteristika. Tidsskr Nor Legeforen 2008; 128: 576-8o. [PubMed]

3. Skinner MK, Gurerrero-Bosagna C, Haque MM et al. Epigenetics and the evolution of Darwin's Finches. Genome Biol Evol 2014; 6: 1972-89. [PubMed][CrossRef]

4. Salvesen KÅB. På tide å innføre fosterdiagnostikk med blodprøver. Tidsskr Nor Legeforen 2018; 138 . doi: 10.4045/tidsskr.18.oo66. [PubMed][CrossRef]

5. Bøhn ED. Hva er galt med transhumanismen? Forskning.no 24.4.2017.

https://forskning.no/blogg/akademiet-yngre-forskere/hva-er-galt-med-transhumanisme (4.2.2019).

Publisert: 25. februar 2019. Tidsskr Nor Legeforen. DOI: 10.4045/tidsskr.19.0110

(C) Tidsskrift for Den norske legeforening 2020. Lastet ned fra tidsskriftet.no 